Fordham University

Fordham Research Commons

2013

\title{
Merging for Survival: An Innovative Collaboration Effort, One Year Later
}

Lauri Goldkind

Graduate School of Social Service, Fordham, goldkind@fordham.edu

Manoj G. Pardasani

Adelphi University

Follow this and additional works at: https://research.library.fordham.edu/gss_facultypubs

Part of the Social Work Commons

\section{Recommended Citation}

Goldkind, Lauri and Pardasani, Manoj G., "Merging for Survival: An Innovative Collaboration Effort, One Year Later" (2013). Social Service Faculty Publications. 13.

https://research.library.fordham.edu/gss_facultypubs/13

This Article is brought to you for free and open access by the Graduate School of Social Service at Fordham Research Commons. It has been accepted for inclusion in Social Service Faculty Publications by an authorized administrator of Fordham Research Commons. For more information, please contact considine@fordham.edu, bkilee@fordham.edu. 
This article was downloaded by: [Fordham University]

On: 28 January 2014, At: 12:58

Publisher: Routledge

Informa Ltd Registered in England and Wales Registered Number: 1072954 Registered

office: Mortimer House, 37-41 Mortimer Street, London W1T 3J H, UK

\section{Administration}

in Social Work

\section{Administration in Social Work}

Publication details, including instructions for authors and subscription information:

http:// www. tandfonline.com/loi/ wasw20

\section{Merging for Survival: An Innovative Collaboration Effort, One Year Later}

\author{
Lauri Goldkind $^{a}$, Manoj Pardasani ${ }^{a} \&$ Suzanne Marmo ${ }^{a}$ \\ a Graduate School of Social Service, Fordham University, New York , \\ New York, USA \\ Accepted author version posted online: 27 Apr 2012. Published \\ online: 18 Mar 2013.
}

To cite this article: Lauri Goldkind, Manoj Pardasani \& Suzanne Marmo (2013) Merging for Survival: An Innovative Collaboration Effort, One Year Later, Administration in Social Work, 37:2, 199-212, DOI: $\underline{10.1080 / 03643107.2012 .674478}$

To link to this article: http:// dx.doi.org/ 10.1080/03643107.2012.674478

\section{PLEASE SCROLL DOWN FOR ARTICLE}

Taylor \& Francis makes every effort to ensure the accuracy of all the information (the "Content") contained in the publications on our platform. However, Taylor \& Francis, our agents, and our licensors make no representations or warranties whatsoever as to the accuracy, completeness, or suitability for any purpose of the Content. Any opinions and views expressed in this publication are the opinions and views of the authors, and are not the views of or endorsed by Taylor \& Francis. The accuracy of the Content should not be relied upon and should be independently verified with primary sources of information. Taylor and Francis shall not be liable for any losses, actions, claims, proceedings, demands, costs, expenses, damages, and other liabilities whatsoever or howsoever caused arising directly or indirectly in connection with, in relation to or arising out of the use of the Content.

This article may be used for research, teaching, and private study purposes. Any substantial or systematic reproduction, redistribution, reselling, loan, sub-licensing, systematic supply, or distribution in any form to anyone is expressly forbidden. Terms \& Conditions of access and use can be found at http://www.tandfonline.com/page/termsand-conditions 


\title{
Merging for Survival: An Innovative Collaboration Effort, One Year Later
}

\author{
Lauri Goldkind, Manoj Pardasani, and Suzanne Marmo \\ Graduate School of Social Service, Fordham University, New York, New York, USA
}

\begin{abstract}
Nonprofit human services providers are struggling to meet increasing demands for services with diminished budgetary resources. This study returns to a unique collaborative fundraising model one year later in order to assess the progress toward successful joint fundraising a year after an initial study of the partnership was completed. Key stakeholders from the two remaining partner agencies were interviewed using a semi-structured interview protocol. Two major themes arose from examining the data: the primacy of relationships in building a successful collaboration and the importance of sustainability and accountability to the well-being of the new organization. The authors discuss practice implications as well as important considerations for other leaders considering the implementation of such a model.
\end{abstract}

Keywords: accountability, identifying possible partners, inter-organizational relationships, organizational sustainability

\section{INTRODUCTION}

In today's environment of scarce resources and increasing competition, organizations in the nonprofit marketplace are developing creative strategies for survival. This study presents follow-up research on a project documenting how three child welfare organizations banded together to create a fourth entity, The Foundation. The Foundation was founded as a vehicle for generating revenues for the partner agencies via planned giving. The nonprofit sector has experienced substantial growth over the past two decades, both in the number of organizations and in the size of existing organizations (Yurenka, 2007). The increased number of nonprofits has prompted concern from the nonprofit community, elected representatives, and government agencies due to increased competition for scarce donation resources (Foster \& Meinhard, 2002; Sargent, Shang, \& Shabbir, 2010; Yurkenka, 2007).

The author's initial research examined the Foundation's inception of the new program model, along with anticipated strengths and weaknesses of implementing this program model among three established charity organizations. This present research returns to the Foundation over one year from the initial interviews to gain a greater understanding of the Foundation's collaborative model, its successes and challenges in the course of the past year, plus possible predictors for success for future organizations seeking to implement this program model.

Correspondence should be addressed to Lauri Goldkind, Graduate School of Social Service, Fordham University, 113 West $60^{\text {th }}$ Street, $7^{\text {th }}$ Floor, New York, NY 10023, USA. E-mail: goldkind@ fordham.edu 
The creation of the Foundation's collaborative model addressed the needs of the founding agencies for new revenue channels by building shared capacity around fundraising through planned giving. Prior to agency collaboration, each partner agency understood the need to begin planned giving campaigns and of utilizing planned giving strategies. Due to resource constraints and a lack of technical expertise, the partners expressed doubt that without the creation of a new collaborative entity they would not have individually undertaken such a project on their own.

Given the novelty of the model, and the possible complexities of planned giving tactics, the authors conducted follow-up interviews with key stakeholders in order to understand the progress made by the Foundation, its on-going successes and challenges, as well as implications for possible predictors of success for organizations planning to pursue similar interagency collaboration.

\section{PURPOSE OF STUDY}

In 2009, the authors first interviewed the key actors participating in a unique inter-agency collaboration model. Using qualitative methods, they described The Foundation, an entity created via the shared commitment, resources, and labor of three private nonprofit organizations. Those conversations and findings are documented in the authors' article (Goldkind \& Pardasani, 2012), "More than the sum of its parts: An innovative organizational collaboration model."

The authors discussed the Foundation's purpose, viz., the utilization of planned giving as a vehicle for shared fundraising effort across three child-welfare organizations situated in a major metropolitan area. Now, over one year later, the authors return to the key actors involved in the creation of the Foundation in order to learn how the collaboration is working, if the new organization is sustaining itself, and what, if any, changes have occurred since initial start up. Group follow-up interviews were conducted with the stakeholders including: executive directors, board members, and the development staff from the partner agencies. The purpose of this study was to re-visit the Foundation as a collaborative model and learn of its progress and growth over time. Additionally, the authors uncovered accountability and organizational sustainability issues that may enhance or hamper the longevity of such an enterprise.

A growing literature on interagency collaboration draws from many theoretical perspectives in order to further our understanding of why nonprofits choose organizational collaboration (Campbell, 2009; Guo \& Acar, 2005; Sowa, 2009). This study synthesizes elements of resource dependency theory and network theory to provide a framework for examining the initial results that may be observed after collaborations have become formalized. The Foundation's outcomes and successes, and lack thereof, became clear throughout the interview process. The central themes the authors uncovered focus on two areas: the primacy of partner relationships and sustainability issues including ongoing fundraising and accountability needs.

\section{LITERATURE REVIEW}

Mergers and formal collaborations are pervasive but not well-understood phenomena in the nonprofit world. Over the last decade there has been an increased interest in the formation of alliances among nonprofits ranging from partnering to deliver services to mergers where one agency subsumes all of the resources of another (Graddy \& Ferris, 2007; Golensky \& DeRuiter, 1999; Kohm \& LaPiana, 2003; Pietroburgo \& Wernet, 2004; Guo \& Acar, 2005). A recent Bridgespan study reports that a review of 11 years of merger filings in four states yielded 3,300 organizations engaging in at least one merger event, for a cumulative merger rate of $1.5 \%$ (number of deals divided by average number of organizations for 11 years) (Cortez, Foster, \& Milway, 2009). 
A review of the literature suggests three prevailing beliefs about how mergers might benefit organizations: the potential for increased efficiency, increased effectiveness, and stability in times of fiscal and political uncertainty (Graddy \& Ferris, 2007; La Piana \& Hayes, 2005). Yet, Campbell (2009) describes the complex nature of a leader's motivation to merge and suggests that a single motivator model is insufficient to accurately describe how leaders approach the complicated notion of merging their agency with another. Frequently there are compelling pros and cons both for and against organizations engaging in a merger process, and often agency executives are pressured to act quickly. Network theory and resource dependency theory may help shed light on the intricate merger processes and motivations.

\section{Partner Relationships and Network Theory}

The original Foundation partnership was a collection of three child welfare organizations who via their organizational networks came together to create a fourth entity, the Foundation (Goldkind \& Pardasani, 2012) . The initial successful outcomes of the partnership of two of these organizations may be linked to the positive relationships and mutual benefits for the key stakeholders within this structure. Organizations, like people, are embedded in social networks. Utilized effectively, these relationship networks can create opportunities for growth and collaboration among those within social network. Granovetter (1985) first described this concept of "embeddedness" as a central component of network theory when applied to organizations. From this perspective, the higher the quality and capabilities of relationships embedded in an organization's network, the greater the potential for organizational growth when partnering with these agencies.

The importance of the quality of relationships in interagency collaboration has been well documented as a necessary component for successful outcomes. A previous positive informal relationship and shared mission has been determined to be a predictor for successful outcomes in formal collaborations (Small, 2011; Wilson, 2010). In a study of the process of moving from informal to formal partnerships with organizations dedicated to combating human trafficking, Small (2011) identified that a history of informal collaboration before the establishment of a formal partnership increased the longevity and success of these partnerships.

Previous positive relationships between board members and key agency personnel have been identified as key elements for strategic partnership and successful agency collaboration (Guo \& Acar, 2005). These pre-established positive operation networks can act as building blocks for interagency collaboration. Previous positive board membership relations within this operation network have been identified as an important element for successful inter-organizational restructuring (Campbell, 2009). Additionally, a 2004 study of nonprofit hospices identified that, despite the wishes for collaboration from hospice agency employees, a lack of board support and board members' negative perceptions of potential partners were impediments to successful agency collaboration, (Pietroburgo \& Werner, 2004).

The Ontario Trillium Foundation, a Canadian governmental organization that helps fund mergers and collaborations, reviewed case studies of organizational mergers and determined full commitment from leadership, mutual benefit, and "compatible organizational cultures" to be preconditions for successful collaborations of not-for-profits (Dessanti \& Miller, 2011). The concept of mutual benefit appears often when addressing necessary preconditions for collaboration, and the significance of all members of the collaboration complementing the other partners has been suggested for effective cross-sector organizational structure (Babiak \& Thibault, 2009).

\section{Sustainability and Resource Dependency Theory}

The process of interagency collaboration can be seen as an adaptation to an uncertain environment during economic downturns in the financial market. Critics of the recent popularity of interagency 
collaboration have downplayed its usefulness as a symbolic ideology rather than a strategy to improve consistent positive service outcomes and organizational sustainability (Longoria, 2005). But as the funding and social service environment changes, agencies are more likely to pursue these collaborations for tangential gains rather than symbolic gestures. In contrast to collaboration occurring for the purpose of symbolism and ideology within an agency, resource dependency theory emphasizes the actual process of exchange and power relations within organizations and, more specifically, how these organizations interact and adapt to their uncertain environments. Initially conceived by Pfeffer and Salancik (1978), resource dependency theory links the sustainability or strength of an organization to its ability to adjust to its changing environments. "Because organizations import resources from their environments, they depend on their environments. Survival comes when the organization adjusts to, and copes with, the environment, not only when it makes efficient internal adjustments" (Pfeffer \& Salancik, 2003).

Scholars and researchers have explored many different motivations for organizations to engage in interagency collaboration, but survival is at the core of all these motivations. They can be motivated by either governmental mandate or competition for governmental funding to maintain organizational viability (Arya \& Lin, 2007; Guo \& Acar, 2005; Longoria, 2005). A study of human service organizations in Los Angeles County showed that the greater the degree of formalized collaboration that occurred in these nonprofit agencies, the higher the likelihood of continued governmental funding and thus, organizational stability (Garrow, 2010).

Competition for financial support from charitable donations has also been increasing during the recent fiscal crisis. During times of economic downturn, charitable organizations are finding it necessary to compete for funding from donors, and successful organizations have had to meet financial challenges by finding new and innovative approaches to continue to meet the financial needs of the organization (Foster \& Meinhard, 2002; Protess \& Roose, 2011). Also reflected in the research on organizational collaboration is the motivation to maintain organizational survivability through reducing operational costs. In a research study of 20 child care agencies that engaged in interagency collaboration, Sowa (2009) identified "the desire to prolong organizational survival" as a factor in interagency collaborations. Dewey and Kaye (2007), in a study of 22 nonprofit organizations, identified a common motivation for organizational mergers as saving one of the more vulnerable organizations involved in the merger from financial failure. In contrast to agency's merging for agency survival, there is minimal research in the social work literature about social service agencies collaborating for long-term sustainability within the constructs of a formalized agreement to raise funds such as was the purpose of the formulation of the Foundation.

Rather than being reactive to governmental mandate or organizational survival, the Foundation's motivation for collaboration seems to be coming from a proactive position, or power position, to promote long-term organizational sustainability. This power position may be more consistent with the theoretical basis of resource dependency theory. Davis and Cobb (2009) identify power as a key component to resource dependency theory and further suggest that greater power within an organization can lead to greater ability to manage uncertain external environments. In this view, the power that will emerge in the collaboration process is not within an immediate financial savings, but in the preservation or sustainability of the organization. The ability to make such a proactive move requires careful strategic planning and resources that are more common in larger, more established organizations. These are qualities possessed by the original partners involved in the Foundation, as opposed to smaller organizations that tend to pursue merger for the sake of survivability. Guo and Carr's (2005) study of 95 urban charitable organizations drew on principles of resource dependency theory, but found that smaller organizations were less inclined to collaborate for survivability. Instead, their research found that larger organizations with greater resources were more likely to participate in formalized collaborations. A 2002 study of 645 nonprofit organizations in Canada also found that small organizations were less likely to engage in formal inter-organizational activities (Foster \& Meinhard, 2002). These two studies could be perhaps suggestive of larger organizations having the 
wherewithal to pursue inter-agency collaborations. Additionally, the Guo \& Carr study suggests that larger, more well-established organizations may be more attractive for potential interagency collaboration, thus increasing the tendency for larger organizations with more resources to participate in these partnering relationships in a more formalized manner (Guo \& Carr, 2005).

\section{METHODOLOGY}

The authors used qualitative methods, specifically structured interviews and open coding, to explore key constituents' experiences creating, starting, and operating a joint fundraising organization. Two structured group interviews were conducted between June 2010 and July 2010. One group interview included the two executive directors of the founding partner agencies. The second group interview included a board member who was also a founding partner of the Foundation, the development staff that are also board members of the Foundation, and a board member of the Foundation who has left one of the partner agencies. Interview questions were organized around three broad areas: organizational sustainability, partner relationships, and future plans. Table 1 describes the interview questions.

The executive directors' interview was held at the offices of one of the partner agencies and the second board and development staff interview was held at a location unrelated to either of the partner agencies. All interviews took place in the metropolitan area where the agencies are situated. All participants provided written informed consent. As stated in the author's prior study, the authors have no prior relationships with the agencies or the Foundation.

\section{Participants}

Senior leadership of the partner agencies as well as senior level individuals who are board members of the Foundation consented to be interviewed. The two executive directors participated in one interview and five board members from the Foundation participated in an additional interview.

TABLE 1

Interview Questions

\begin{tabular}{ll}
\hline Area of Investigation & \multicolumn{1}{c}{ Questions } \\
\hline Organizational Sustainability & What kinds of changes has the Foundation undergone in the past year? \\
What has been the response of the board to this past year? & How will the Foundation be supported financially? \\
Does the board intend to fundraise for the Foundation? What avenues of support are \\
being considered? \\
What, if any, milestones, goals and/or objectives did the Foundation achieve this year? \\
Has the Foundation realized any gifts? \\
What would the criteria look like to consider new organizational members of the \\
Foundation? \\
What kinds of fee arrangements are being considered (for new partners)? \\
Have you been approached by any organizations, either to join the Foundation or to \\
inquire about how they can replicate your model? \\
Has the Foundation considered charging new members to participate? \\
What are the plans for marketing for the coming year? \\
Are there any lessons learned from previous events? \\
Thinking about the future, do you anticipate the culture and/or approach of the \\
Foundation changing with the addition of new members? \\
Future Plans
\end{tabular}




\section{The Foundation}

The Foundation is an incorporated nonprofit entity founded in 2007. The founders of the Foundation are the development and executive directors of Agency A and B. It was incorporated as an organization whose mission is to promote planned giving programs on behalf of the founding agencies. Each agency has committed a volunteer to serve as a board member who is also a board member of the founding agency's board. A professional advisory council comprised of lawyers, accountants, private equity analysts, estate and financial planners are being cultivated to promote the existence of the Foundation and offer the Foundation as a possible recipient donor vehicle to their clients. Members of the professional advisory council have been cultivated from the networks of development staff at the founding agencies. The Foundation operates with small budget contributions from each of the original organizations and also benefited from a two-year start-up grant provided by a local private foundation interested in inter-agency collaboration. Table 2 describes characteristics of the two partner agencies.

Many of the fundraising and distribution policies that the Foundation will require in order to expand successfully are still evolving. At the time that interviews were conducted the Foundation was still navigating the licensing requirements of annuity writing as well as wrestling with the possible growth strategies in terms of inviting new agencies to participate. In its original inception, a three-agency partnership model, all gifts realized by the Foundation would be disbursed equally across partner agencies.

\section{Data Analysis}

Interviews were recorded using an Olympus WOW SRS digital recorder and transcribed verbatim. Transcripts were imported into a qualitative software program to facilitate analysis (Atlas.ti 6). The co-authors, two of whom conducted the interviews and one who did not participate in the interview process, used an iterative process to identify a broad range of categories pertaining to subjects' understanding of the organization's developmental trajectory. The open-ended responses were coded with techniques suggested by Strauss and Corbin (1990). This process included independent reading and coding of the transcripts to identify codes, comparison between investigators, and refinement of conceptual categories via consensus-building discussion (Strauss \& Corbin, 1990). In the open coding phase of data preparation, the authors generated more than 40 unique codes. After the authors believed they had reached the point of saturation where coding was becoming redundant, they met and compared their results (Padgett, 1998). The next step was the distillation of those codes based on relatedness, shared meanings, overlap, and definitions into six major conceptual categories (categories are described in Table 6.). The authors proceeded based on processes outlined by Strauss and Corbin (1990), Miles and Huberman (1994), and Marshall and Rossman (1999), who suggest open coding to first break the data down into discrete parts and apply codes to it, then to compare and contrast the codes and group sets of similar codes into conceptual categories.

TABLE 2

Summary Partner Agency Information as Reported in the 2008 IRS 990

\begin{tabular}{lccccccc}
\hline & $\begin{array}{c}\text { Clients } \\
\text { served }\end{array}$ & $\begin{array}{c}\text { Board } \\
\text { members }\end{array}$ & Total budget & $\begin{array}{c}\text { Government } \\
\text { contracts }\end{array}$ & $\begin{array}{c}\text { Medicare/ } \\
\text { Medicaid }\end{array}$ & $\begin{array}{c}\text { Private } \\
\text { gifts/grants }\end{array}$ & $\begin{array}{c}\text { Interest } \\
\text { income }\end{array}$ \\
\hline Agency 1 & 7,300 & 34 & $\$ 60,069,137$ & $\$ 43,000,000$ & $\$ 9,000,000$ & $\$ 2,000,000$ & $\$ 800,000$ \\
Agency 2 & 5,500 & 23 & $\$ 9,127,674$ & $\$ 3,000,000$ & $\$ 3,000,000$ & $\$ 4,000,000$ & 0 \\
\hline
\end{tabular}




\section{FINDINGS \& DISCUSSION}

The open coding process yielded three major themes: loss of partner, sustainability, and quality of relationships. These themes seemed to play a critical role in supporting the continued potential of the merger.

\section{Loss of Partner}

One of the most significant events experienced by the Foundation since its founding was the loss of one of the three founding partners. The associate executive director at the departing agency left his position and the incoming executive director did not want to pursue the collaboration. The departing associate executive director also happened to be the individual who first floated the idea of the Foundation to the executive directors of the other two agencies. Thus the remaining partners were dealt a serious blow.

I think the fact that the leaving the partnership ... and I am sorry to see them go, I would [have] preferred not to have the transition, I would prefer to have the stability. (ED\#1)

The reasons provided for the departure of one of the partner agencies were not entirely clear.

In the [last] year one of our member agencies left ... due to their time and ability to be part of the Foundation, and maybe other factors that we are not privy to. (Departing Associate ED)

One of the potential reasons provided for the departure was a lack of commitment from the board at the departing agency.

Right, yeah, very important that there's board support. And that's probably one of the reasons why the agency never really completely came totally connected because of the lack of someone from the board. (Departing Associate ED)

Other reasons offered for the departure were the lack of a prior working history between the incoming executive director and the current executive directors, as well as a lack of confidence in the Foundation's potential to generate revenue on part of this person.

Questions regarding a replacement for the departing member yielded critical discussions regarding the issue of goodness-of-fit, financial stability, and mission compatibility. These were the same issues that contributed to the initial founding of the merger as evidenced in our first article. In highlighting their proposed criteria for a new partner, both the executive directors and the development staff discussed the importance of inviting an agency that had a similar focus in terms of population served, services provided, and organizational history. The participants were concerned that the merger would not be strengthened if the new member's mission was significantly different than that of the other two. They believed that compatible missions and established histories of service in the New York region were the cornerstones of their initial partnership as well as their continued marketing focus. In other words, they felt that their efforts at joint fundraising would be negatively impacted if the partners had divergent missions or foci.

I think more of a fit in terms of missions would be important. I think given the legacy all two organizations have ... some of the, may also have some history [which] would be appreciated, because if they're going back to the marketing thing, what's the whole, what are you buying into? (ED\#2)

In terms of thinking of someone or the agency, we also wanted the agency to have-I guess similarnot the same the mission but working within the social services. And also a great plus would be an agency that had historical roots. (Development Officer \#2)

The participants also believed that any incoming partner would have to buy into the idea of joint fundraising through planned giving initiatives, which is at the core of the Foundation's mission. 
... someone who really sees it as a way for them-sees the investment side of it for their agency, and sees it as a long-term investment. (Development Officer \#2)

We stressed to the board we don't want to rush the decision either. We want to make sure it's the right decision, and whoever we're asking we want to make sure that they realize it's sort of like an interview. We want to make sure it's a win-win. (Associate ED)

Another criterion highlighted by the remaining partners was the incoming member's financial stability. While not directly addressed, the partners alluded to the fact that the departing member agency may have been experiencing some financial challenges and that this may have precipitated their decision to leave the merger. Thus, the two remaining partners suggested that apart from compatible missions, financial stability of an agency might become a critical issue for consideration. However, it was not clear how the current partners would evaluate the stability of a potential new member agency.

We want to make sure it's a win-win-just because we approached them doesn't mean it's an automatic that they're gonna be accepted it, because we want to make-you know some of the other board members expressed concern about making sure someone has some financial stability. (Development Officer \#1)

\section{Sustainability}

The continued viability and sustainability of this merger were seriously threatened by the loss of a founding member. Given that the CSG has only had three members, the departure of one of the founding members was a critical blow. Compounding this loss was the downturn in the U.S. economy just as the Foundation was being established as a separate entity. Both agencies reported that their individual fundraising efforts had been negatively impacted by the economic crisis. Additionally, they believed that the efforts of the Foundation to expand its donor base were also thwarted by this unexpected downturn.

We had hoped last—not last fall but the fall before-to really start actually implementing the whole planned giving things and then the market crashed. (Development officer \#2)

I think it remains to be seen when the economy kind of comes back, but I hope that will happen. (ED\#2)

Yeah, and we've had 18 months of real free fall. There's no two ways about that. (ED\#1)

Another factor that threatens the sustainability of the merger is the lack of resources, both in terms of manpower and fiscal support. The Foundation does not have any staff at this time. The development officers volunteer their time to the merger. While the Foundation does have an operating board, it is mostly comprised of board members from the two member agencies, as well as the development officers. It also includes an attorney who is responsible for setting up the financial and legal mechanisms required to engage in planned giving. The board has been engaged in developing the bylaws of the new Foundation and seeking official approvals for their future planned giving endeavors. Thus, they have not had time to devote to raising revenues or operating resources for the Foundation.

And we don't necessarily have the capacity to do that, and going back to the whole economy kind of thing, you know, we shared a lot-a quarter of my full-time staff, it was a killer, it was a killer. . . We really can't spare any [staff]. (ED\#2)

The original merger was supported by small start-up grant of $\$ 50,000$ from a local foundation, which has now been exhausted. The members have discussed some ideas for revenue generation to support the Foundation; however, they report that these discussions have only been preliminary. The members proposed the idea of charging membership fees for incoming members to provide 
additional financial resources for operations. However, no fee structure has been established at this time. The executive directors of both agencies have also proposed an idea for contributing a set amount of money to the Foundation themselves. They believed that their boards would be supportive of this short-term plan for shoring up the Foundation.

You know prior to that gift coming through, we had already made a commitment, and an agreement to fund the regular operations at the Foundation, with us putting in equal, and that agreement stands . . . But those agencies are committed to supporting this Foundation financially. (ED\#1)

We were talking about the ideas [new members], because of various potential opportunities for revenue for the Foundation. (ED\#1)

With reference to manpower, the participants would like to appoint a part-time staff member to guide the Foundation. They believe that this would significantly strengthen the merger. However, at the current time there is no established revenue stream to fund this position. A part-time Foundation coordinator would manage communication across Foundation board members, member agencies, and external stakeholders. Additionally, the coordinator would assist with event production, donor acknowledgement, and donor database management.

Because of that [start-up grant ending], it's allowed us to look at the possibility of having staffyou know part-time staff through the agency as opposed to just doing it, doing everything ourselves. (Development Officer \#1)

A principal guiding motivation for the establishment of the Foundation was to augment the fundraising efforts of the founding agencies. The founding members believed that the Foundation could leverage substantial funds for the members through the utilization of sophisticated planned giving instruments. They also felt that a joint venture would be more appealing to large funders as it would promise a more comprehensive impact in the social service arena. In the two years since the establishment of the Foundation, it has realized several pledges of support. But all these pledges have been made by the current board members of the two remaining agencies.

As of today, Children's Village has two gifts signed in place, and we're working on three more. (ED\#1)

"And so LG helped us create this, you know, the Legacy Society, and then that vehicle you know she was an inaugural member of that, and then another trustee, and so we got those two, and that was great. (ED\#2)

So, while the Foundation has allowed the partners to realize additional revenues from their board members, it has not yielded any revenues from "outside" funders. The Foundation has organized several workshops and social networking events to introduce themselves to individual and Foundation donors. But these have not yielded any additional funds to the Foundation. This is of concern to the executive directors and the development officers. They highlighted the urgent need to restrategize and enhance their marketing efforts to reach out to additional donors. They highlighted a two-pronged approach to marketing and fundraising.

\footnotetext{
"One would be the short-term, which is to have sponsors, which basically cover the events, cover our ability to have educational cultivation events, and then on a larger scale we've been using our professional advisory council to help us connect with larger donors. (Development Officer \#2)
}

The agencies believe that given the current economic climate, fundraising may be a tough endeavor. They believe that the lack of follow-up with attendees at these events may have resulted 
in the lack of contributions. Once again, the need for a staff member devoted to the operations of the Foundation was highlighted by the participants.

I'd I rather put-have fewer events and put that energy into whatever the next event would have been to follow up with the people from the last one... They maybe need a phone call, you know they just need a phone call. And we don't necessarily have the capacity to do that. (ED\#2)

One challenge to the ongoing sustainability of the merger may be the limited outcomes realized by the founding members. However, the participants argued that the funds currently raised are a sign of the success of this model. They also discussed the importance of dissemination of their model. The participants highlighted that they have been discussing their model with other agencies, development officers, and foundations around the country. They believe that this will lend credibility to the Foundation and allow it to leverage additional resources. This dissemination would be important not just for attracting new fee-paying members, but also for potential donors. Without documentation of the impact of this Foundation, donors and agencies may be unwilling to commit their resources to the Foundation.

I thought what the Foundation would do was create a new identity and sell the product to new donors that could benefit all three of us, that our combined reputations would make it more palatable to a new donor that may not want to just give to one agency. (ED\#1)

And we probably had about10 people come to find out more specifically about how Children's Support Foundation worked and to talk about what they were doing to see if it was a fit for them and to learn more about it. (Development Officer \#1)

I probably was contacted - I can think specifically of three times, and different things happened like when there was a piece that we did for [Non Profit News] and when something was in The Chronicle or the New York Times. (Associate ED)

Another challenge highlighted by the members was the need to develop and strengthen their organizational structure. Given the departure of one of the founding members and the establishment of a board, many issues need to be addressed in order to secure the Foundation. Concrete plans for staffing, recruiting new members, marketing, outcome evaluation, planned giving initiatives, and developing an advisory council have to be developed and executed. If these issues are not resolved, it will seriously threaten the sustainability and viability of this merger.

I think that as we grow as a Foundation, potentially grow as it has different sources of revenue and things that are going on that we sort of stay sort of true to our original mission that the first priority is to grow the agencies who are involved. (Associate ED)

So at this point they're just I think trying to nurture the development of this organization. (ED\#2)

One positive factor that may allow the Foundation to address their challenges and move forward is the buy-in from the board members at both the agencies. The executive directors reported enthusiastic and robust support from their boards. They added that boards realize that progress with the Foundation may be slow and labored and are prepared to support it for the long haul. This support and commitment may buffer the merger from any imminent threats of failure. However, if eventual progress is not made with generating outside revenues, the support may be lessened.

So I would say similarly for us the big achievement was I feel like we got our board to understand this in a deep enough way to go, "Alright, I'll—and make a gift." (ED\#1).

Our board representation on the Children's Support Foundation has been extremely supportive and a very vocal cheerleader for the whole [merger]. (ED\#2) 


\section{Nature of Relationships}

An undercurrent of our discussions was the relative importance accorded to relationship chemistry. Both the executive directors and the development officers noted their desire to work with partners that they "gelled" with. The executive directors highlighted that the reason for the continued existence of the Foundation was the strong bond of friendship and mutual respect shared between them and their staff. They believe that the trust they have established over the years and their complementary personalities have been critical to their partnership. Thus, they expressed a desire to invite new members who would contribute positively to this healthy rapport. A collaborative working style, confidence in joint fundraising, focus on mutual benefit, and a compatible personality were identified as the key ingredients for a potential new partner.

We know each other, we are cohesive. (ED\#1)

We talked a little bit about—not in any formal way-criteria, but you know it's not a matter of adding anybody-someone we feel very strongly about, so you really want a partner that would fit, that would be a good fit. (ED\#2)

... But we wanted the third agency that would come on a potential or immediate level, for the first areas of recruitment to be one obviously that they could share that easy dialogue with. (Associate $E D)$.

\section{Limitations}

The authors recognize several limitations in reporting on this phenomenon. The two main limitations of this follow-up study are the generalizablity of the authors' findings given the subjective nature of interpreting qualitative results and the small sample size; and secondly, this characterization of the work of the Foundation suffers from the lack of information provided by the leaders of Agency $\mathrm{C}$ because the partner opted to leave the Foundation project after one year. The generalizability of qualitative work has been the subject of great debate (Chenail, 2010), but many researchers acknowledge the value that qualitative research methods provide for strategic and descriptive observation of unique phenomenon (Rubin \& Babbie, 2010). Additionally, the sample size of one offers obvious threats to external validity, and we acknowledge that our study is a single-case design. Despite this method's limitations, the potential value of a single-case design such as this one lies in the comprehensive observation of complex social circumstances to search for "deeper meanings or inherent explanations" (Dudley, 2011, p. 251). The complexity involved in interagency collaboration may be better understood utilizing this approach. Additionally, due to the uniqueness of the Foundation's program model, the authors know of no other similar merger model of its kind anywhere in the United States and, on that merit, in addition to the likely high degree of merit for other human services executives considering a partnership of this type, the Foundation is a model worthy of analysis.

The other limitation to the study is the lack of input and participation from Agency C, or the agency that elected to remove themselves from the Foundation project. An invitation to participate was extended to the leadership of Agency $\mathrm{C}$ and the executive director declined to be interviewed for this study. It is important to note that the departing agency experienced a leadership change as well as change in senior development staff. In addition, a board member, a critical component of success as identified in the authors' prior article on this subject matter (Goldkind \& Pardasani, 2012) was never invested in the project. While the new leader of Agency C exercised an opinion of the project by discontinuing the agency's involvement, it may have been instructive to hear from them firsthand their thoughts and experiences with the project and its key constituents. 


\section{Implications}

This Study raises some important issues for human services leadership considering planned giving as an avenue for diversifying their funding base or for other reasons. The economic downturn has placed significant constraints on funding, and the prolonged nature of the financial crisis has led, in extreme cases, to some agencies closing their doors, while other better-resourced organizations look for creative survival strategies.

As the U.S. economy suffers, philanthropic giving to nonprofit organizations has progressed in a downward spiral (Banjo \& Kalita, 2010; Protess \& Roose, 2011). This follow-up study has provided the authors with great access at years one and two of a new organization's existence to understand the motivations of the founders and to gain a greater understanding of the challenges human services leaders face even in the face of great opportunities. The two biggest implications to arise from this research have been the complexities inherent in building a planned giving strategy and the strengths and challenges of sustainability to a new organizational model.

The authors heard throughout the interviews with key stakeholders that all of the partners dramatically underestimated the level of complexity in engaging in a planned giving campaign. In particular, the Foundation was started as a mechanism for all of its founding or partner organizations to be able to write charitable gift annuities. Given the multifaceted nature of such gifts and the unfortunate economic climate, the Foundation has yet to realize its first planned gift, despite being two years old. However, the individual board members of the partner agencies have realized sizable gifts for their agencies through the Foundation. Another by-product of being involved in the startup of the Foundation has been an enhanced and heightened understanding of the many dimensions of planned giving. Although the Foundation has yet to realize planned gifts successfully, one of the founding organizations (Agency A) has had more than three planned gifts bestowed on the organization. And in the case of Agency B, a "legacy" or bequest society has begun as a direct result of being involved in the Foundation-a side project that has already yielded greater investment on behalf of several board members.

Other significant areas of impact that leaders and board members should consider are the accountability structures and agreed-upon outcomes needed to quantify for sustainability. A major theme raised in the executive directors' interviews was the desire to create interim benchmarks and measurable outcomes in order to increase transparency and evaluate successes and challenges. Similar to many of the other hard-to-document successes in the human services, a planned giving program, particularly one designed to develop relationships with donors and produce complex financial instruments, will take a substantial amount of time to realize significant benefits. Everyone interviewed articulated a desire to quantify success beyond counting gifts, but nowhere was this clearer than in discussions with executive directors. A key issue that will impact the success of the Foundation and others interested in replicating similar mergers is how to measure success in terms of tangible written annuity. Leaders interested in models of donor diversification should consider the level of resources they are willing to invest in beginning a planned giving initiative, the level of board commitment for such an initiative, and the varying levels of complexity they believe their existing and projected donor base can endure.

Finally, the sustainability of the merger was found to be dependent on financial stability of the current partners and the search for new partners. As noted in Guo and Carr's (2005) study, the financial stability of the partner organizations is a critical component in the sustainability of the merger. One of the Foundation's founding partners left the partnership due to issues with financial stability and a change in management. With respect to new partners, in concurrence with Dessanti and Miller's (2011) study, we found that the remaining partners were more concerned about mission and personal compatibility than with raising additional operational revenues through membership dues. 


\section{CONCLUSION}

The authors have illustrated a merger model that is unique in that no one agency has given up or subsumed identify under the umbrella of another. Rather, two of the three original founding agencies have created a fourth organization, the Foundation, whose purpose is to promote planned giving on behalf of the partners. It is the authors' belief that that this follow-up study can provoke questions and new thinking on behalf of agency administrators about the benefits and challenges of collaborations and the complexities of planned giving. Additional follow-up will demonstrate the successes and challenges of partners working in close alliances on joint fundraising projects. One indelible lesson of the Foundation is the great need for training on effective fundraising strategies and advanced funding and donor diversification strategies such as charitable gift annuities, bequests, and charitable remainder trusts so that agency leaders can make informed decisions as to how to invest their human and fiscal resources in the name of diversifying their revenue streams. The authors hope to conduct a final round of follow-up interviews with the principals of the participating organizations at the five-year mark in order to continue to document the growth and evolution of this unique model.

\section{REFERENCES}

Arya, B., \& Lin, Z. (2007). Understanding collaboration outcomes from an extended resource- based view perspective: The roles of organizational characteristics, partner attributes, and network structures. Journal of Management, 33(5), 697-723.

Babiak, K., \& Thibault, L. (2009). Challenges in multiple cross-sector partnerships. Nonprofit and Voluntary Sector Quarterly, 38, 117-143.

Banjo, S., \& Kalita, S. M. (2010, February 2). Once-robust charity sector hit with mergers, closings. Wall Street Journal. Retrieved from http://online.wsj.com/article/SB10001424052748704586504574654404227641232.html? mod=WSJ_hpp_MIDDLETopStories

Campbell, D. A. (2009). Giving up the single life: Leadership motivations for interorganizational restructuring in nonprofit organizations. Administration in Social Work, 33(4), 368-386.

Chenail, R. J. (2010). Getting specific about qualitative research generalizability. Journal of Ethnographic \& Qualitative Research, 5(1), 1-11.

Cortez, A., Foster, W., \& Milway, K. S. (February, 2009). Nonprofit mergers and acquisitions: More than a tool for tough times. Boston, MA: The Bridgespan Group. Retrieved from http://www.bridgespan.org/Nonprofit-M-and-A.aspx

Davis, G. F., \& Cobb, J. A. (2010). Resource dependency theory: Past and future. In C. B. Schoonhoven \& F. Dobbin (Eds.), Stanford's organization theory renaissance, 1970-2000 (Vol. 28; pp. 21-43.) Bingley, UK: Emerald Group.

Dessanti, V., \& Miller, J. (2011). Mergers: Not a four-letter word. Ontario, Canada: Ontario Trillium Foundation. Retrieved from http://www.trilliumfoundation.org/en/knowledgeSharingCentre/mergers.asp

Dewey, K. R. \& Kaye, M. (2007). Nonprofit mergers: An assessment of nonprofits' experiences with the merger process. Tropman Reports, 6(2), 1-9.

Dudley, J. R. (2011). Research methods for social work: Being producers and consumers of research. Boston, MA: Pearson Education.

Foster, M. K., \& Meinhard, A. G. (2002). A regression model explaining predisposition to collaborate. Nonprofit and Voluntary Sector Quarterly, 31(4), 549-564.

Garrow, E. E. (2010). Receipt of government revenue among nonprofit human service organizations. Journal of Public Administration Research and Theory, 21, 445-471.

Graddy, J. M., \& Ferris, E. A. (2007). Why do nonprofits merge? Retrieved from http://cppp.usc.edu/doc/FINAL_ RP28_GraddyFerris_10_29.pdf

Golensky, M., \& DeRuiter, G. L. (1999). Merger as a strategic response to government contracting pressures. Nonprofit Management \& Leadership, 10(2), 137-156.

Granovetter, M. (1985). Economic action and social structure: The problem of embeddedness. American Journal of Sociology, 91(3) 481-510.

Guo, C. \& Acar, M. (2005). Understanding collaboration among nonprofit organizations: Combining resource dependency, institutional, and network perspectives. Nonprofit and Voluntary Sector Quarterly, 34(3), 340-361.

Kohm, A., \& LaPiana, D. (2003). Strategic restructuring for nonprofit organizations: Mergers, integrations, and alliances. Westport, CT: Praeger Publishers. 
LaPiana, D., \& Hayes, M. (2005). Play to win: The nonprofit guide to competitive strategy. San Francisco, CA: John Wiley $\&$ Sons.

Marshall, C., and Rossman, G. B. (1999). Designing qualitative research (3rd ed.). Thousand Oaks, CA: Sage Publications.

Miles, M. B., \& Huberman, M. (1994). Qualitative data analysis: An expanded sourcebook (2nd ed.). Boston, MA: Sage Publications.

Padgett. D. K. (1998). Qualitative methods in social work research. Thousand Oak, CA: Sage Publications.

Pietroburgo, J., \& Wernet, S. P. (2004). Joining forces, fortunes and futures: Restructuring and adaptation in nonprofit hospice organizations. Nonprofit Management and Leadership, 15(1), 117-137.

Protess, B., \& Roose, K. (2011, August 30). Charities struggle with smaller Wall Street donations. The New York Times.

Pfeffer, J., \& Salancik, G. R. (2003). The external control of organizations: A resource dependency perspective. Stanford, CA: Stanford University Press.

Rubin, A., \& Babbie, E. R. (2010). Essential research methods for social work (2nd ed.). Belmont, CA: Brooks/Cole, Cengage Learning.

Sargent, A., Shang, J., \& Shabbir (2010). The social marketing of giving: A framework for public policy intervention. Public Management Review, 12(5), 635-662.

Small, K. (2011). The role of anti-human trafficking community partnerships in the identification of and response to human trafficking victims in the United States (Doctoral dissertation, The American University) No. AAT 3255087. Available from ProQuest Dissertations \& Theses database, http://www.proquest.com (UMI No. 3255087)

Strauss, A., \& Corbin, J. M. (1990). Basics of qualitative research: Techniques and procedures for developing grounded theory. Thousand Oaks, CA: Sage Publications.

Wilson, R.R. (2010). The synergy of modern abolition: Inter-agency cooperation between state agencies, religious communities, faith-based organizations and NGO's against human trafficking (Master's dissertation, Baylor University). Available from ProQuest Dissertations \& Theses database. (UMI No. 1488170)

Yurenka, D. (2007). Growth in the nonprofit sector and competition for funding. Retrieved from http://economics.uchicago. edu/pdf/yurenka_nonprofit.pdf 